
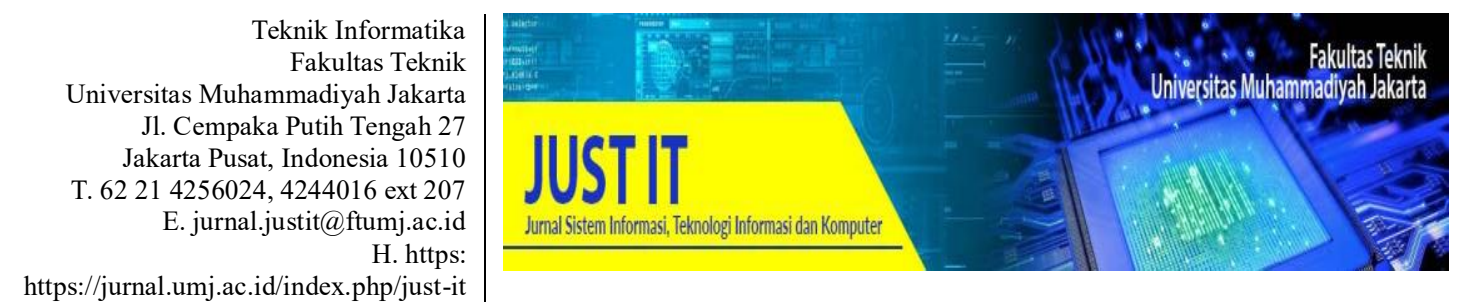

\title{
PERANCANGAN APLIKASI SISTEM ADMINISTRASI RAWAT JALAN KLINIK SUKAMAJU DEPOK
}

\author{
Mega Oktavia ${ }^{1}$, Thomas Afrizal ${ }^{2}$, Michael Sonny ${ }^{3}$. \\ Fakultas Teknik dan Ilmu Komputer, Universitas Indraprasta PGRI \\ Jl. Raya Tengah No.80 Kelurahan Gedong, Pasar Rebo, Jakarta 13670 \\ megaaaao14@gmail.com
}

\begin{abstract}
ABSTRAK
Dalam dunia usaha dan bisnis, peranan teknologi informasi sangat dibutuhkan.Mengelola data menjadi informasi merupakan peranan dari teknologi informasi yang sangat berguna seperti halnya di Klinik Sukamaju Depok. Dalam proses bisnisnya, klinik sukamaju depok belum menggunakan sistem komputerisasi yang baik. Hal ini kurang baik, karena akan mengakibatkan pelayanan yg kurang baik dan efisien. Oleh karena itu peneliti melakukan penelitian yang bertujuan untuk meningkatkan efisiensi dan kualitas pelayanan, serta meminmalisir kesalahan dan keamanan data pasien. Metode penulisan yang digunakan oleh penulis dalam tugas akhir ini adalah metode Research and Development yaitu metode yang digunakan untuk mengembangkan suatu produk baru atau menyempurnakan produk yang telah ada, dan dapat dipertanggung jawabkan. Penulis menarik kesimpulan bahwa sistem administrasi yang dibangun dapat mempermudah klinik dalam penanganan pendataan dan perhitungan serta pembuatan laporan dengan mudah.
\end{abstract}

Kata kunci: : Klinik, administrasi, pasien, pelayanan, rawat jalan.

\section{ABSTRACT}

In the business and business world, the role of information technology is very much needed. Managing data into information is the role of information technology that is very useful as in the Sukamaju Clinic in Depok. In its business process, Depok Sukamaju Clinic has not used a good computerized system. This is not good, because it will lead to services that are less good and efficient. Therefore researchers conducted research aimed at improving the efficiency and quality of service, as well as minimizing errors and the safety of patient data. The writing method used by the writer in this thesis is the Research and Development method, which is the method used to develop a new product or improve existing products, and can be justified. The author draws the conclusion that the administration system that is built can facilitate the clinic in handling data collection and calculation and making reports easily.

Keywords: Klinik,administration, patient,care, outpatient

\section{PENDAHULUAN \\ Latar Belakang}

Perkembangan teknologi informasi pada era globalisasi mempengaruhi aspek kehidupan manusia. oleh karena itu, teknologi informasi sangatlah penting yang bertujuan untuk mempermudah manusia dalam menjalani hidup dan aktivitas sehari-hari. Definisi teknologi informasi menurut (Sutabri, 2014) Teknologi informasi adalah suatu teknologi yang digunakan untuk mengolah data dalam berbagai cara untuk menghasilkan informasi yang berkualitas, yaitu informasi yang relevan, akurat dan tepat waktu, yang digunakan untuk berbagai keperluan dan merupakan informasi yang strategis untuk 
pengambilan keputusan. Oleh karena itu kemajuan teknologi sangat berguna bagi setiap orang, baik individu maupun kelompok. Peningkatan kebutuhan informasi perlu mendapatkan perhatian dan penanganan yang tepat, sehingga hasil yang dicapai sesuai yang diinginkan.

Untuk mendapatkan hasil yang maksimal harus diimbangi dengan peralatan penunjang yang canggih yaitu aplikasi untuk mengolah berbagai macam data atau kegiatan. Dengan menggunakan aplikasi diharapkan setiap kegiatan dapat dilakukan dengan mudah dan menghemat waktu. Peneliti menyimpulkan bahwa kemajuan teknologi informasi sangat berguna untuk pengolahan data termasuk memproses, mendapatkan, menyusun, menyimpan, memanipulasi data dalam berbagai cara untuk menghasilkan informasi yang berkualitas. Dalam mewujudkan pemanfaatan dari teknologi informasi, maka diperlukan sebuah aplikasi yang berguna dalam kegiatan pelayanan masyarakat. Salah satu kegiatan pelayanan masyarakat yang umum yaitu pelayanan klinik. Klinik membutuhkan aplikasi dalam bidang pelayanan seperti administrasi, pendaftaran pasien, pengolahan data rekam medis pasien. Salah satu klinik yang membutuhkan aplikasi untuk pengelolaan administrasi yaitu klinik sukamaju Di klinik Sukamaju ini masih terdapat cara kerjanya yang manual mulai dari pendaftaran pasien yang masih dicatat menggunakan buku, hasil pemeiksaannya pun dicatat yang dapat menimbulkan kegandaan pendapatan pasien dan data pribadi baik pasien maupun dokter, penjadwalan dokter lalu pencarian data masih belum terkomputerisasi sehingga membutuhkan waktu yang lama dan juga kurang efisien dalam melakukan pencarian berkas atau data. Untuk itu peneliti berusaha menyusun serta merancang sistem komputer dengan memilih judul "Perancangan Aplikasi Sistem Administrasi Rawat Jalan Klinik Sukamaju Depok". Dengan menggunakan teknik komputerisasi diharapkan dapat meningkatkan efisiensi dan kualitas pelayanan serta dapat meminimalisir kesalahan dan keamanan pasien.

\section{Tujuan Penelitian}

Dari uraian pada tujuan penelitian, maka peneliti memberi sejumlah tujuan penelitian sebagai berikut:

1. Tujuan dari penelitian ini adalah untuk mengetahui informasi pengolahan data pasien, data dokter, data pembayaran dan data rekam medis yang berjalan di Klinik Sukamaju Depok

2. Penelitian ini membuat sebuah aplikasi untuk membantu Klinik yang belum terkomputerisasi

3. Dengan membuat sebuah aplikasi ini dapat tersimpan rapi dalam bentuk file dan dapat membantu petugas klinik dalam mengolah data penjadwalan rawat jalan.

\section{Manfaat Penelitian}

Manfaat penelitian dalam tugas akhir ini adalah sebagai berikut :

1.Dapat berguna dalam menambah wawasan dan pengetahuan serta penglaman dibidang kesehatan, khususnya pelayanan klinik terhadap pasien dan menambah penerapan teori pada kuliah yang sedang dijalani.

2.Penelitian ini untuk membantu dan mempermudah dalam pelayanan medis dan pengolahan data pasien

3.Hasil ini dapat memberikan tambahan pengetahuan dan dapat menjadi bahan referensi, bagi pihak-pihak yang akan mengkaji informasi dan melakukan penelitian yang sama.

\section{METODE PENELITIAN}

Menurut (sugiyono, 2016), "Metode penelitian merupakan cara ilmiah untuk memperoleh data, dengan tujuan dan kegunaan tertentu".

Metode yang digunakan oleh penulis adalah metode Research and Development, yaitu Metode penelitian yang digunakan untuk menghasilkan produk tertentu, dan menguji keefektifan produk tersebut (sugiyono, 2016) Selain itu Research and Development juga suatu proses atau langkah - langkah untuk mengembangkan produk yang telah ada, yang dapat dipertanggung jawabkan. Produk tersebut tidak selalu berbentuk benda atau perangkat keras (hardware), seperti buku, modul, alat bantu pembelajaran dikelas atau laboratorium, tetapi bisa juga perangkat lunak (software), seperti program komputer 
pengolah data, pembelajaran dikelas, perpustakaan atau laboratorium, ataupun model - model pendidikan, pembelajaran, pelatihan, bimbingan, evaluasi, manajemen, dan lain - lain.

\section{Metode Pengumpulan Data}

Metode yang digunakan untuk pengumpulan data secara pengambilan keterangan yang dibutuhkan untuk merancang program dalam penelitian ini dilakukan dengan cara :

\section{Metode Kepustakaan}

Dilakukan dengan cara mempelajari bukubuku literatur dan jurnal-jurnal ilmiah mengenai sistem administrasi, dan sistem rawat jalan pasien.

\section{Metode Lapangan}

Dilakukan secara langsung oleh peneliti dengan melakukan observasi, yaitu mempelajari dan mengamati bagaimana sistem administrasi rawat jalan pasien serta keterkaitan antara subsistem yang satu dengan yang lainnya. Dilengkapi dengan wawancara kepada Dr desy selaku pemilik klini untuk kepentingan pengumpulan data, mulai dari alur sistem yang berjalan sampai dengan aturan bisnis yang berlaku pada klinik tersebut. Setelah itu penulis melakukan dokumentasi, berupa pendataan bagian bagian yang penting dari sistem administrasi yang diperlukan sebagai bahan penelitian.

\section{Studi Pustaka}

Yakni metode pengumpulan data dengan cara mempelajari buku, sarana perpustakaan, dan catatan-catatan kuliah yang berhubungan dengan yang diajukan. Peneliti membaca buku yang terkait dengan perancangan sistem bisnis, juga peneliti mendatangi perpustakaan Universitas Indraprasta untuk melihat dan membaca skripsi yang terkait dengan sistem administrasi dan sistem rawat jalan dalam klinik. Dan catatan kuliah yang peneliti baca selama perkuliahan yang terkait dengan pembuatan sistem administrasi

\section{Angket}

Angket atau kuesioner merupakan teknik pengumpulan data yang dilakukan dengan cara memberi seperangkat pertanyaan atau pernyataan tertulis kepada responden untuk dijawabnya (sugiyono, 2016). Angket diberikan pada pemilik klinik untu mendata para pasien

\section{HASIL DAN PEMBAHASAN}

Sistem yang diusulkan pada penilaian secara keseluruhan dalam bentuk diagram konteks dan ERD (Entity Relationship Diagram) adalah sebagai berikut :

\section{Diagram Konteks}

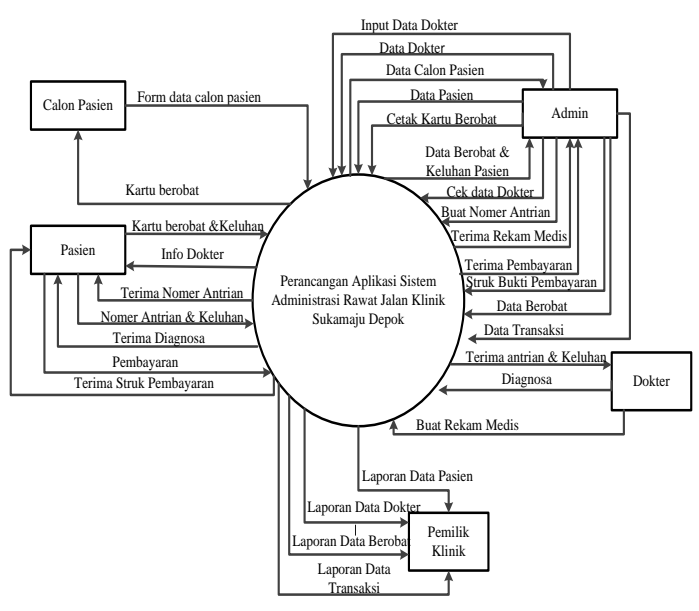

Gambar.1 Diagram Konteks yang Diusulkan

\section{Entity Relationship Diagram (ERD)}

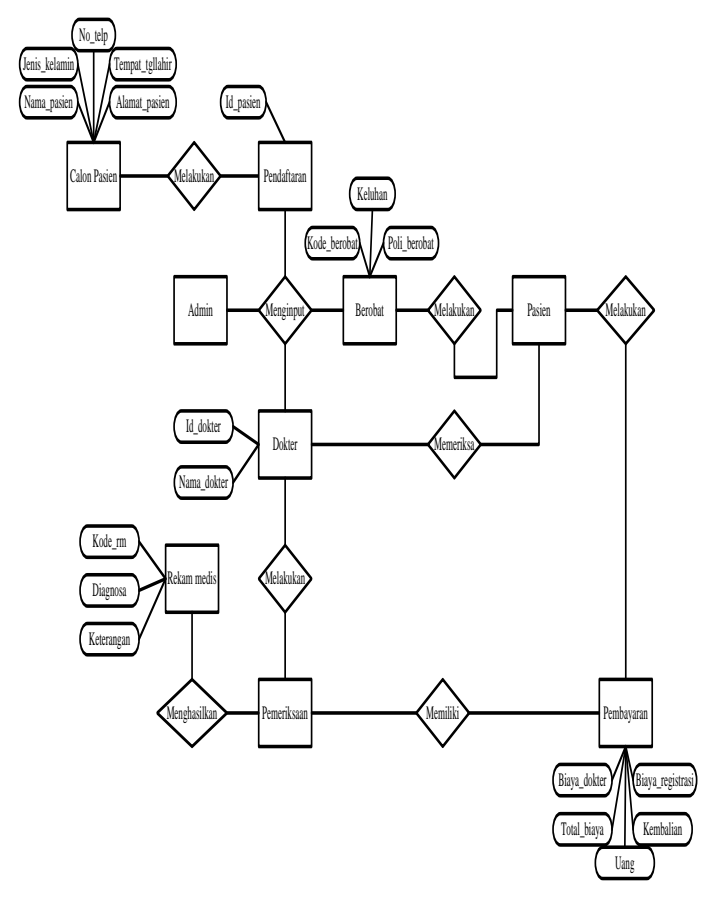

Gambar.2 ERD yang diusulkan

Selanjutnya penulis membuat aplikasi menggunakan java dan database mysql. Berikut ini adalah tampilan dari Perancangan Aplikasi Sistem Administrasi 
Rawat Jalan Klinik Sukamaju Depok :

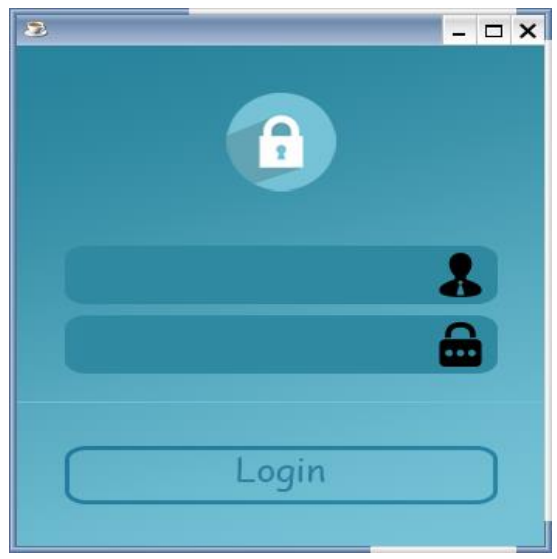

Gambar 3. Login

Tampilan form login ini muncul di awal saat pengoprasian program sistem sistem administrasi rawat jalan pasien.untuk diisi oleh admin sebagai user. Masukkan username dan password yang sesuai dengan hak akses supaya bisa mengoprasikan sistem administrasi rawat jalan pasien. Jika username dan password sesuai, maka akan masuk kepada tampilan Menu Utama.

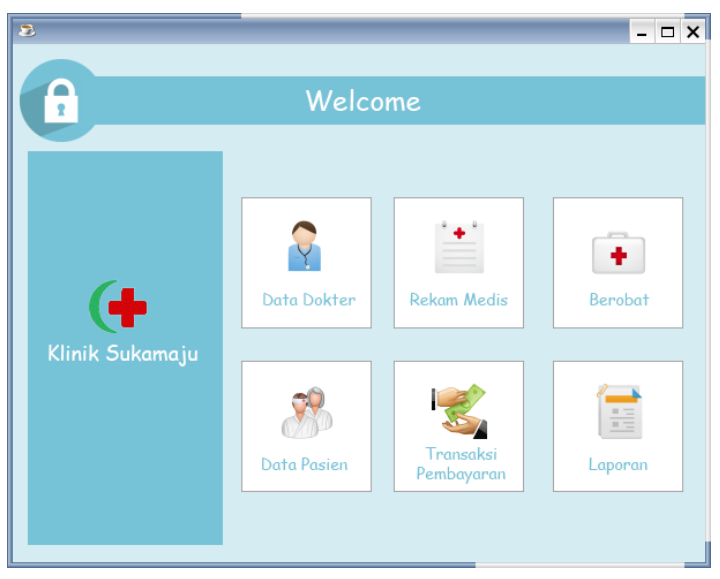

Gambar 4. Menu Utama

Tampilan Menu Utama ini terdapat beberapa icon menu yang akan menampilkan form-form masukkan data diantaranya:

a. Data dokter akan menampilkan input data dokter

b. Data Pasien, akan menampilkan input data pasien.

c. Berobat, akan menampilkan input data berobat d. Rekam medis, akan menampilkan input rekam medis

e. Transaksi Pembayaran, akan menampilkan input transaksi pembayaran

f. Laporan, akan menampilkan data laporan dokter, pasien, berobat, dan transaksi pembayaran

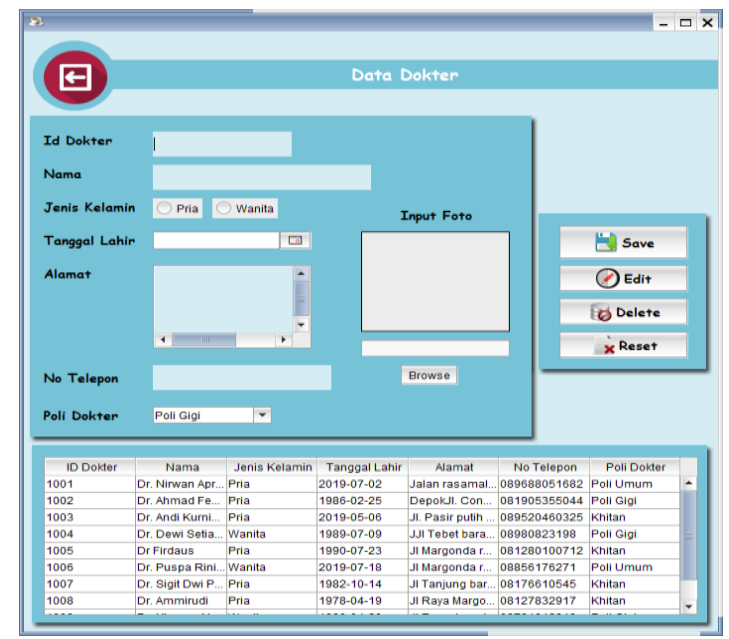

Gambar 4. Tampilan Menu Data Dokter

Tampilan Form data dokter ini, user dapat melakukan penambahan data dokter, mengubah, dan menghapus data dokter. Masukkan id dokter untuk melakukan pengecekan data-data yang sudah tersimpan. Lakukan pengisian apabila akan dilakukan penambahan data dan tekan tombol (save) untuk menyimpan data, untuk memperbaharui data tombol (edit), dan untuk menghapus data klik tombol (delete). Untuk mengahapus data yg belum di save di form, klik tombol (reset)

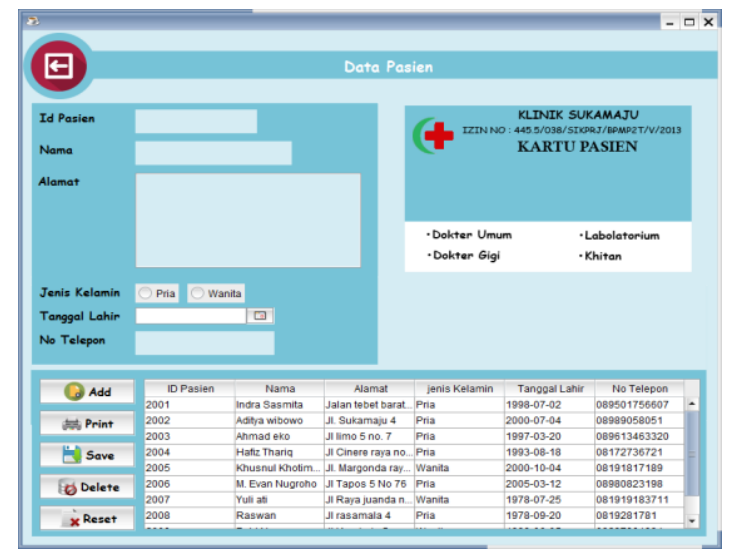

Gambar 5. Tampilan Data Pasien 
Tampilan Form data pasien ini, user dapat melakukan penambahan data pasien, mengubah, dan menghapus data pasien. Masukkan id pasien untuk melakukan pengecekan data-data yang sudah tersimpan. Lakukan pengisian apabila akan dilakukan penambahan data dan tekan tombol (save) untuk menyimpan data, untuk memperbaharui data tombol (edit), dan untuk menghapus data klik tombol (delete). Untuk mengahapus data yg belum di save di form, klik tombol (reset). Untuk menambahkan data ke kartu, tekan tombol (add) dan untuk mencetak data klik tombol (print).



Gambar 6. Tampilan Data Berobat

Tampilan Form data berobat ini, user dapat melakukan penambahan data berobat, mengubah, dan menghapus data berobat. Masukkan kode berobat untuk melakukan pengecekan data-data yang sudah tersimpan. Lakukan pengisian apabila akan dilakukan penambahan data dan tekan tombol (save) untuk menyimpan data, untuk memperbaharui data tombol (edit), dan untuk menghapus data klik tombol (delete). Untuk mengahapus data yg belum di save di form, klik tombol (reset).

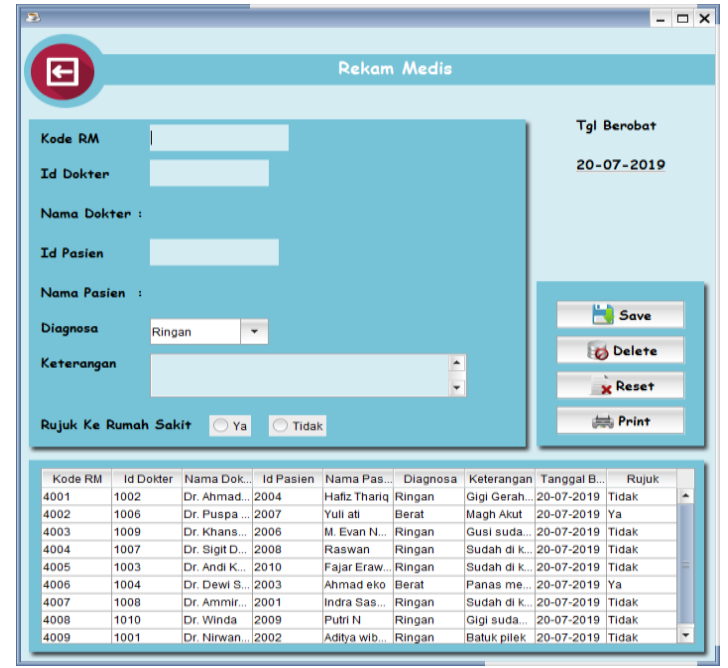

Gambar 7. Tampilan Rekam Medis

Tampilan Form data rekam medis ini, user dapat melakukan penambahan data rekam medis, mengubah, dan menghapus data rekam medis. Masukkan kode rm untuk melakukan pengecekan data-data yang sudah tersimpan. Lakukan pengisian apabila akan dilakukan penambahan data dan tekan tombol (save) untuk menyimpan data, untuk memperbaharui data tombol (edit), dan untuk menghapus data klik tombol (delete). Untuk mengahapus data yg belum di save di form, klik tombol (reset).

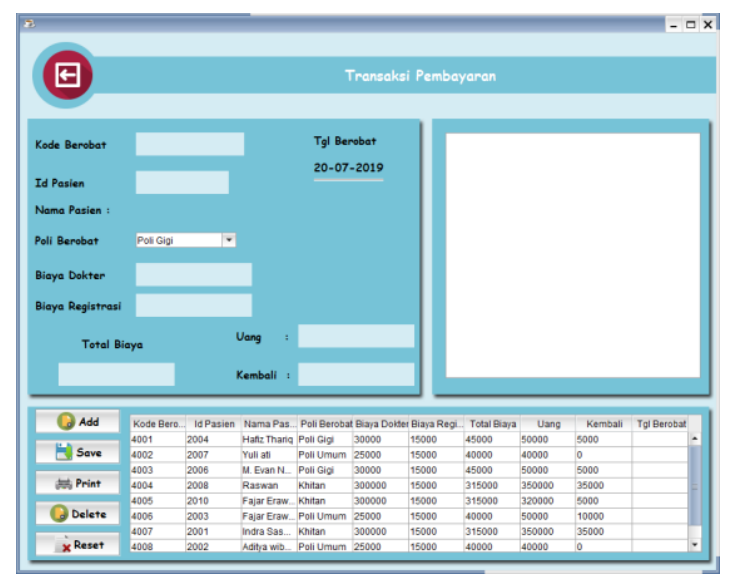

Gambar 8. Tampilan Data Transaksi

Tampilan Form data transaksi ini, user dapat melakukan penambahan data transaksi, mengubah, dan menghapus data transaksi. Masukkan kode berobat untuk melakukan pengecekan data-data yang sudah tersimpan. Lakukan pengisian apabila akan dilakukan penambahan data dan tekan tombol (save) untuk menyimpan data, untuk memperbaharui 
data tombol (edit), dan untuk menghapus data klik tombol (delete). Untuk mengahapus data yg belum di save di form, klik tombol (reset). Untuk menambahkan data ke struk, tekan tombol (add) dan untuk mencetak data klik tombol (print).

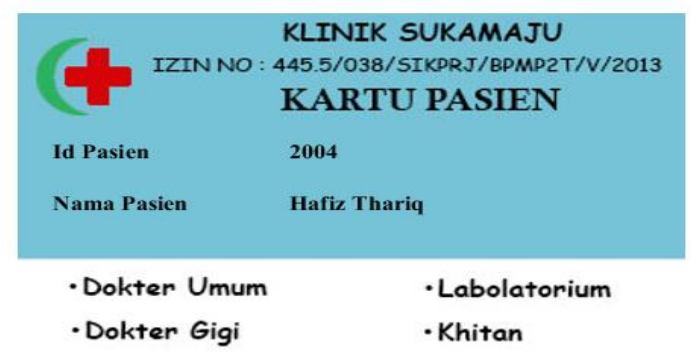

Gambar 9. Tampilan Kartu Berobat

Tampilan kartu berobat ini memuat data pasien yaitu id pasien dan nama pasien yang harus dibawa setiap kali berobat ke klinik.

\section{Nomor Antrian Klinik Sukamaju}

asd

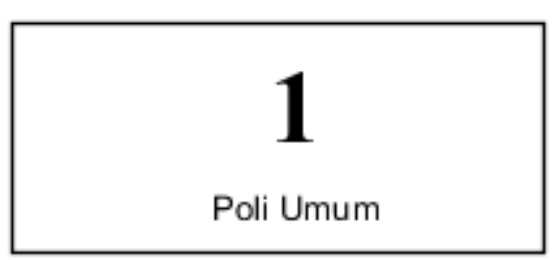

Gambar 10. Tampilan Nomer Antrian

Tampilan kartu berobat ini memuat Nomer antrian pasien yaitu nomer antrian, poli berobat dan nama staff yg bertugas.

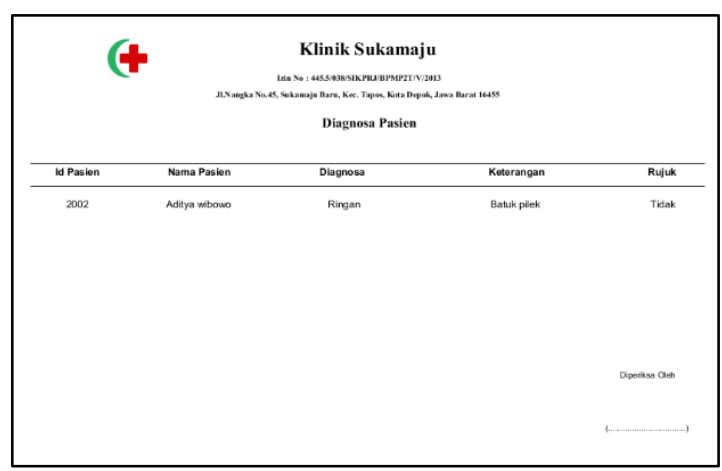

Gambar 11. Tampilan Diagnosa Pasien
Tampilan Diagnosa Pasien ini memuat data diagnosa pasien yaitu id pasien, nama pasien, diagnosa, keterangan dan rujuk rumah sakit yang dibuat setelah pemeriksaan pasien.

\begin{tabular}{|c|c|}
\hline \multicolumn{2}{|c|}{$\begin{array}{c}\text { Klinik Sukamaju } \\
\text { JI.Nangka No.45, Sukamaju Baru, Kec. Tapos, Kota Depok, Janva Barat } \\
16455\end{array}$} \\
\hline \multicolumn{2}{|l|}{ Tanggal Transaksi } \\
\hline Kode Berobat & 4001 \\
\hline Id Pasien & 2004 \\
\hline Nama Pasien & Hafiz Thariq \\
\hline Poli Beroobat & Poli Gigi \\
\hline Biaya Dokler & 30000 \\
\hline Biaya Registrasi & 15000 \\
\hline Total Harga & 45000 \\
\hline Total Bayar & 50000 \\
\hline Kembali & 5000 \\
\hline
\end{tabular}

Gambar 12. Tampilan Struk Pembayaran Pasien

Tampilan Struk Pembayaran Pasien ini memuat data yg harus dibayarkan oleh pasien yaitu biaya dokter dan biaya registrasi pasien.

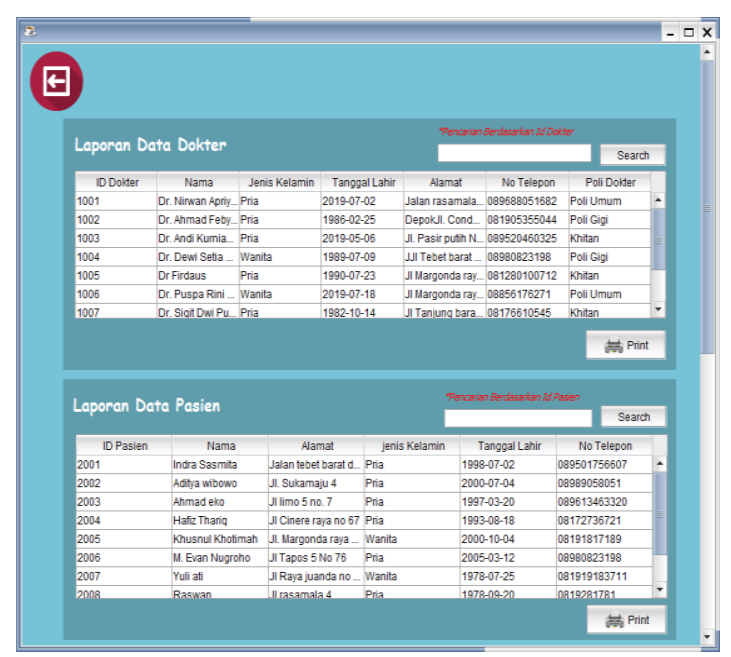

Gambar 13. Tampilan Menu Laporan

Tampilan menu laporan ini digunakan untuk mencetak laporan, yaitu laporan data dokter, data pasien, data berobat, dan laporan transaksi pembayaran. 




Gambar 14. Tampilan Laporan Data Dokter

Tampilan Laporan Data dokter ini berisi datadata yang ada pada tabel dokter Laporan ini muncul ketika user mengklik menu laporan dan laporan dokter pada tampilan menu utama. User bisa mencetak laporan ini dengan mengklik tombol yang berlogo printer yang berada di bagian bawah kanan. Laporan ini di cetak berdasarkan parameter tahun yang diinginkan.
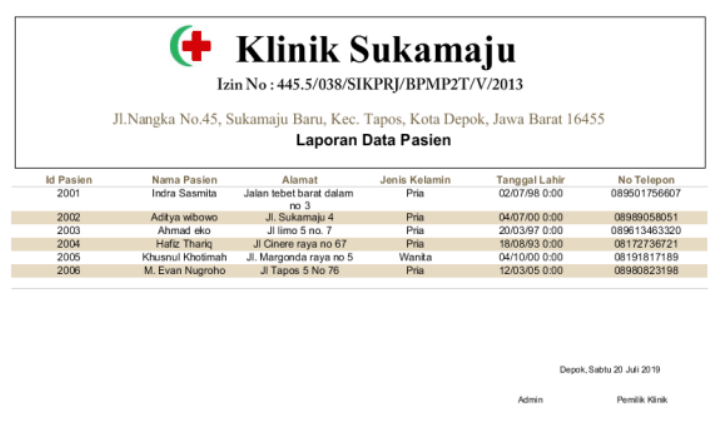

Gambar 15. Tampilan Laporan Data Pasien

Tampilan Laporan Data Pasien ini berisi datadata yang ada pada tabel Pasien. Laporan ini muncul ketika user mengklik menu laporan dan laporan pasien pada tampilan menu utama. User bisa mencetak laporan ini dengan mengklik tombol yang berlogo printer yang berada di bagian bawah kanan. Laporan ini di cetak berdasarkan parameter tahun yang diinginkan.

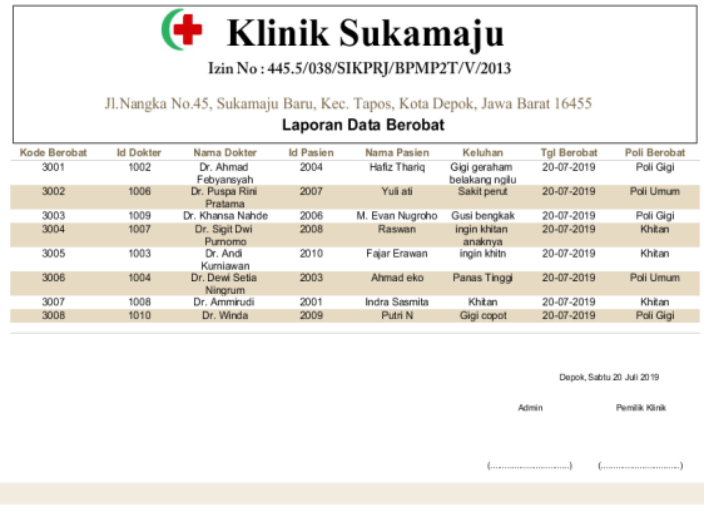

Gambar 16. Tampilan Data Berobat

Tampilan Laporan Data berobat ini berisi datadata yang ada pada tabel berobat. Laporan ini muncul ketika user mengklik menu laporan dan laporan berobat pada tampilan menu utama. User bisa mencetak laporan ini dengan mengklik tombol yang berlogo printer yang berada di bagian bawah kanan. Laporan ini di cetak berdasarkan parameter tahun yang diinginkan.

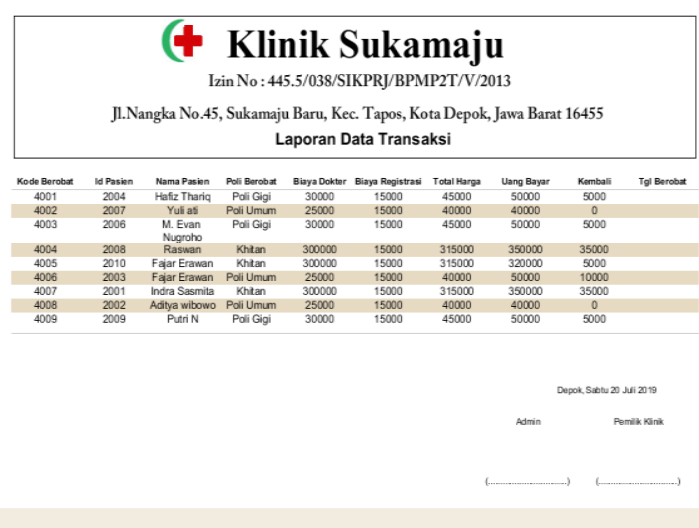

Gambar 17. Tampilan Laporan Data Transaksi

Tampilan Laporan Data Transaksi ini berisi data-data yang ada pada tabel Transaksi. Laporan ini muncul ketika user mengklik menu laporan dan laporan Transaksi pada tampilan menu utama. User bisa mencetak laporan ini dengan mengklik tombol yang berlogo printer yang berada di bagian bawah kanan. Laporan ini di cetak berdasarkan parameter tahun yang diinginkan.

\section{SIMPULAN}

Dari pembahasan bab-bab sebelumnya, peneliti dapat menarik kesimpulan bahwa :

1. Dengan adanya sistem terkomputerisasi 
maka dalam pembuatan laporan yang sebelumnya secara manual dapat dipermudah dan di percepat dengan menggunakan sistem ini.

2. Perkembangan klinik dapat dengan cepat diketahui pimpinan, karena rancangan informasi ini dapat dengan cepat memperoleh laporan-laporan yang diperlukan

3. Proses kerja dalam penyimpanan data lebih mudah dan efisien dapat memberikan informasi yang dibutuhkan pimpinan lebih cepat di proses pada saat dibutuhkan.

\section{Daftar Pustaka}

(Subekti \& Susiyanti, 2015)Setiawan. (2014). Sistem Administrasi Rawat Jalan pada Klinik iliwangi. Jurnal Lentera Ict, 2(1), 76-97.

Subekti, S., \& Susiyanti, R. (2015). Aplikasi Sistem Informasi Administrasi Klinik (Studi Kasus: Klinik Jakarta Skin Center). Jurnal Sisfotek Global, 5(2).

sugiyono. (2016). metode penelitian pendidikan (kuantitatif kualitatif dan $\mathrm{R}$ \& D). Bandung: Alfabeta. https://doi.org/10.1164/rccm.200409$1267 \mathrm{OC}$

Sutabri, T. (2014). Analisis Sistem. In Analisis Sistem Informasi.

(Setiawan, 2014) 